\title{
長䋊維強化 $\mathrm{Ti}$ 基複合材料の超塑性成形
}

\section{山田毅佐藤広明都筑隆之}

\author{
三菱重工業株式会社名古屋航空宇宙システム製作所 \\ J. Japan Inst. Metals, Vol. 65, No. 12 (2001), pp. 1045-1052 \\ (C) 2001 The Japan Institute of Metals
}

\section{Superplastic Forming of Continuous Fiber Reinforced Titanium Matrix Composites}

Takeshi Yamada, Hiroaki Sato and Takayuki Tsuzuku

Nagoya Aerospace Systems, Mitsubishi Heavy Industries, Ltd., Nagoya 455-8515

Sprayed preforms were fabricated with Ti-4.5Al-3V-2Mo-2Fe alloy (SP-700) powder of $23 \sim 53 \mu \mathrm{m}$ diameter instead of conventional powder of $23 \sim 150 \mu \mathrm{m}$ diameter to make the microstructure of the sprayed deposit fine. SCS- $6 / \mathrm{SP}-700$ composite made of the improved sprayed preforms (improved spray composite) showed superplasticity in the tensile direction perpendicular to the fiber with a maximum $m$-value of 0.58 at $1048 \mathrm{~K}$. The tensile flow stress of the improved spray composite was a little lower than that of SCS-6/SP-700 composite made of woven preforms. Tensile strength at room temperature of the improved spray composite after deformation was comparable to that of the improved spray composite before deformation. Stringer- and blade-shaped TMC part models are demonstrated to be successfully superplastic-formed. No debonding defects at fiber/matrix interface were observed in the blade-shaped model using the improved spray composite.

(Received September 5, 2001; Accepted October 2, 2001)

Keywords: titanium matrix composite, titanium alloy, silicon carbide, superplastic forming, sprayed preform, plasma spray, tensile strength, microstructure, stringer, blade

\section{1. 緒言}

高い比強度と耐熱性を備えた様々な先進材料が航空宇宙機 器用構造材料への適用を期待され, 中でも長繊維強化 $\mathrm{Ti}$ 基 複合材料 (以下, TMC) は中間温度域 $(573 \sim 873 \mathrm{~K})$ での適用 が期待されている1). TMC はディスクやブレードなどのエ ンジン部品を中心に, 翼外板や脚等の機体構造部品への適用 が検討され, 部品試作なども行われている ${ }^{2-7)}$. しかし $\mathrm{TMC}$ の部品製造は, プリフォーム段階で所定の形状に付与 した後にネットシェイプに複合化する必要があり, プリフ ォームの熱間予備成形工程, ネットシェイプ複合化工程とも に高価であるため, 部品製造コストが極めて高く, 実用化へ の大きな障害となっている.

部品製造コストを低減する方法の一つとして，TMCを塑 性加工により直接形状付与する方法が考えられる. TMC の 二次加工が可能であれば, 熱間予備成形工程やネットシェイ プ複合化工程は不要となり, 部品製造コストの大幅削減が期 待でき, 複雑な曲面を有するブレードに拈いては特にその効 果が大きいと考えられる. しかし長繊維強化複合材料はこれ まで塑性加工が困難と考えられてきた為, その報告例は極め て少なく，TMCを用いたブレード試作研究において塑性加 工が利用されたと思われる報告例は僅かにあるが2,3), 詳細 に検討した例はない。

そこで著者らは超塑性特性に優れる $\mathrm{Ti}-4.5 \mathrm{Al}-3 \mathrm{~V}-2 \mathrm{Fe}-$ $2 \mathrm{Mo}$ 合金(以下，SP-700)をマトリックス材とし, CVD 法
により製作された $\mathrm{SiC}$ 繊維である SCS-6 を強化繊維とする SCS-6/SP-700 複合材料 (以下, SCS-6/SP-700 材)を開発 し， TMC に超塑性加工技術を適用する低コスト加工プロセ スを提案している8,9). 繊維直交方向での高温引張試験では, SCS-6/SP-700 材が $1048 \mathrm{~K}$ において $m$ 值(ひずみ速度感受 性指数值) 0.58 , 公称伸び $100 \%$ 以上の優れた超塑性特性を 有することを確認している8,9).

一方，超塑性引張試験後の試験片断面を光学顕微鏡で観察 したところ，繊維/マトリックス界面に三種の欠陥が発生す ることが明らかとなった る $^{8}$ との欠陥の一つは界面強度を超 える応力が加えられて䋊維/マトリックス界面が剥離した欠 陥(以下，Type-1 欠陥）である。 あとの二つは変形条件に依 存しない欠陥であり, 繊維を固定するための TiNb リボンに 起因して発生する欠陥 (以下, Type-2) と, 繊維同土が複合 化時から接触していたために部分的にマトリックス不足とな ってできた欠陥 (以下, Type-3)に分類できる. 変形条件の 適正化では Type-2 と Type-3 欠陥を防止することは困難で あるため，繊維の固定に TiNb リボンを用いず，且つ繊維間 隔を均一に制御する目的で，溶射プリフォームを用いた SCS-6/SP-700 材 (以下, 溶射材)を開発して, これらの加 工条件に依存しない欠陥が抑制できることを確認した9)。 た加工条件に依存する Type-1 欠陥については, 完全に防止 することはできなかったものの，低いひずみ速度と変形応力 での変形により欠陥発生を低減できることを確認した ${ }^{9)}$.

$1048 \mathrm{~K}$ において繊維垂直方向に定ひずみ速度 $\left(5 \times 10^{-5}\right.$ $\left.1 \times 10^{-3} \mathrm{~s}^{-1}\right)$ で引張試験を行った場合, 溶射材の变形応力は 
$\mathrm{TiNb}$ 合金リボンで SCS-6 を編んで固定した Woven プリフ オームを用いた SCS-6/SP-700 複合材料(Woven 材)に比べ て高くなることが確かめられている ${ }^{9)}$. 溶射材と Woven 材 の繊維体積率 $\left(V_{\mathrm{f}}\right)$ はそれぞれ $20 \%$ および $27 \%$ であり， $V_{\mathrm{f}}$ が低いにも関わらず溶射材の方が Woven 材に比べて変形応 力が高かった．溶射皮膜のみを積層して熱間静水圧加圧処理 (HIP 処理)により拡散接合した板の変形応力は，SP-700 箔 のみを積層して HIP 処理により接合した板の变形応力の約 2 倍であったことから ${ }^{9)}$, 溶射材のマトリックス部に含まれ る溶射皮膜部に起因して，溶射材の変形応力が高くなってい ると考えられる．この溶射皮膜部のミクロ組織を䇴部と同様 に均一微細な組織に改善できれば，溶射材の変形応力を低減 でき, Type-1 欠陥の発生をより一層抑制できると考えられ る.

本研究では，溶射プリフォームの製造条件を適正化するこ とにより溶射材の変形特性改善を図るとともに，モデル部品 の試作と試作部品の欠陷生成状況および引張強度特性を調べ た.

\section{2. 試 験 方 法}

\section{1 溶射材のミクロ組織観察}

溶射法には溶射雾囲気からの污染が少ない低圧プラズマ溶 射法 (以下, LPS) を選定し，直径 $500 \mathrm{~mm}$ のステンレス製 ドラムに巻いた $\mathrm{SiC}$ 繊維 $(\mathrm{SCS}-6)$ 上に $\mathrm{SP}-700$ 粉末を溶射し てプリフォームを製作した. LPS は真空チャンバー内を 1.2 $\times 10^{-2} \mathrm{~Pa}$ 以下の真空に排気した後, 高純度 $\mathrm{Ar}$ ガスを注入 して雾囲気圧を $1.3 \times 10^{4} \mathrm{~Pa}$ 一定に保ちながら行った。 SCS-6 は Textron Systems 社で製造された平均直径約 142 $\mu \mathrm{m} の \mathrm{SiC}$ 連続繊維で, 直径 $33 \mu \mathrm{m}$ 程度の炭素緘維芯線上 にCVD 法により $\beta-\mathrm{SiC}$ を蒸着し，さらに最外層に約 3.6 $\mu \mathrm{m}$ の SCS コーティングと呼ばれる TC (Turbostratic Carbon) ブロックから構成された炭素マトリックス中に $\beta-\mathrm{SiC}$ 粒子が分散した多層コーティングが施されている10). SP700 は NKK侏で開発された低温で超塑性成形可能な $\beta$ リッ チ $\alpha+\beta$ 合金であり，Ti-6Al-4V 合金に比べ $150 \mathrm{~K}$ 程度低い 973 1073 K の温度範囲で優れた超塑性特性を有する ${ }^{11-14)}$. SP-700 粉末は Ar ガスアトマイズ法により製作し，マトリ ックス材のミクロ組織を均一微細化するために従来は 23 $150 \mu \mathrm{m}$ であった粉末粒径を細かく分粒して，23〜53 $\mathrm{mm}$ 粒 径の粉末を用いた。また SCS-6 繊維はドラム上に $0.25 \mathrm{~mm}$ の間隔を保つように制御しながら専用の装置を用いて巻き付 けた。

複合材料板材は，4層の溶射プリフォームと板厚 $150 \mu \mathrm{m}$ の SP-700 䇤を交互に積層し，ステンレス製カプセル内に真 空封入した後, $\mathrm{Ar}$ ガス圧 $150 \mathrm{MPa}, 1048 \mathrm{~K}-2 \mathrm{~h}$ の条件で HIP 処理により製作した. 複合化温度は従来 $1023 \mathrm{~K}$ で行っ てきたが，予備試験において接合が不十分な箇所が認められ たため，従来の条件より $25 \mathrm{~K}$ 高い $1048 \mathrm{~K}$ とした。複合材 料板材の寸法は $1.4 \mathrm{~mm} \times 80 \mathrm{~mm} \times 150 \mathrm{~mm}$ であり， $V_{\mathrm{f}}$ は平 均 $22 \%$ であった。 また溶射材の断面組織観察は光学顕微鏡 により行った.

\section{2 常温引張試験および塑性変形特性試験}

溶射粉末を微細にし，複合化温度を $25 \mathrm{~K}$ 上げるという製 造条件の変更を行った溶射材の常温引張試験と塑性変形特性 試験を行った．溶射材は 2.1 項と同様の供試材を用い，比較 の為に Woven 材も供試材として用いた. Woven 材は 4 層 の Woven プリフォームと板厚 $150 \mu \mathrm{m}$ の SP-700 䈃を交互 に積層し, ステンレス製カプセル内に真空封入した後, 溶射 材と同様に Ar ガス圧 $150 \mathrm{MPa}, 1048 \mathrm{~K}-2 \mathrm{~h}$ の条件で HIP 処理により製作した．Woven 材板材の寸法は $1.2 \mathrm{~mm} \times 120$ $\mathrm{mm} \times 200 \mathrm{~mm}$ であり, $V_{\mathrm{f}}$ は平均 $27 \%$ であった.

常温引張試験および塑性変形特性試験に用いた試験片の形 状と寸法を Fig. 1 に示す. 常温引張試験は繊維配向方向に クロスヘッド速度 $0.5 \mathrm{~mm} / \mathrm{min} の$ 条件で行った。また塑性 変形特性試験では緎維直交方向に定ひずみ速度引張試験を行 い，变形応力および破断ひずみを測定した。試験温度は $1048 \mathrm{~K}$ とし，ひずみ速度は $5 \times 10^{-5} \mathrm{~s}^{-1}, 2 \times 10^{-4} \mathrm{~s}^{-1}, 1 \times$ $10^{-3} \mathrm{~s}^{-1}$ の三条件で, 破断するか公称ひずみで $100 \%$ まで引 張り, 変形応力は真ひずみが $10 \%$ のきの值で整理した.

\section{3 ストリンガー形状モデル成形試験}

欠陥生成挙動並びに超塑性成形後の SCS-6/SP-700 複合 材の常温引張強度測定を行う為に, Fig. 2 に示すような深さ の異なる二種類のストリンガー形状モデルをガス圧負荷によ り成形する試験を行った。供試材には 2.1 および 2.2 項と同 様の条件で製作した溶射材および Woven 材を用いた。成形 温度は $1048 \mathrm{~K}$ であり，成形部の最大ひずみ速度が $2 \times 10^{-5}$ $\mathrm{s}^{-1}, 5 \times 10^{-5} \mathrm{~s}^{-1}, 5 \times 10^{-4} \mathrm{~s}^{-1}$ となるようなガス圧を負荷し

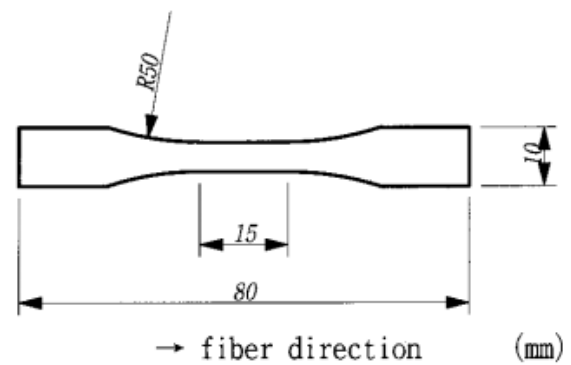

(a) Specimen for tensile test at R.T.

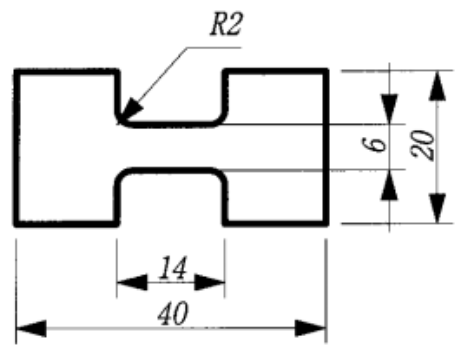

(b) Specimen for superplastic deformation test

Fig. 1 Schematic of tensile specimens used in this study. 


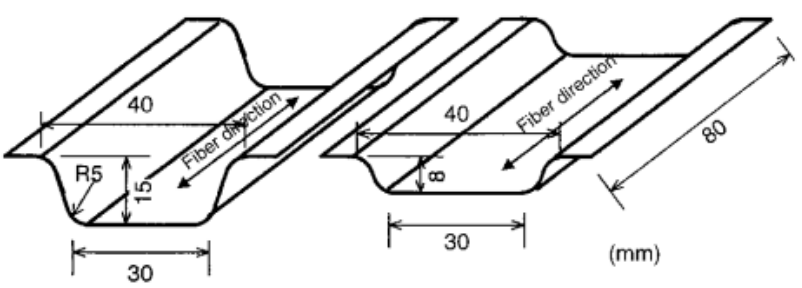

(a) Deep

(b) Shallow

Fig. 2 Schematic of stringer-shaped models.

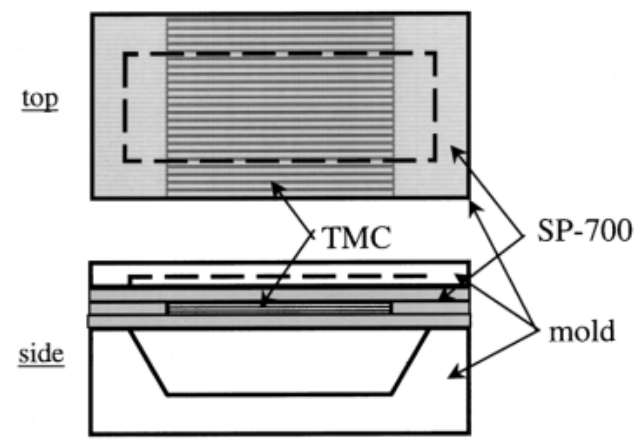

Fig. 3 Schematic of apparatus used for the fabrication of stringer-shaped model using packed TMC blanks.

て成形を行った。 また本成形試験では，Fig. 3 に示すように $\mathrm{SCS}-6 / \mathrm{SP}-700$ 複合材料板の上下を板厚 $1 \mathrm{~mm}$ の SP-700 板 材ではさみ, この積層体を一枚の板材とみなしてパン形状に ガス圧負荷成形することで，複合材料部分がストリンガー形 状に成形されるように工夫した。 この時, 複合材料は繊維直 交方向の久拘束を受けるように，複合材料は繊維直交方向の 端部のみ成形治具で挟んで固定した. 試験後, 供試体の底面 部より Fig. 1(a)に示す形状の試験片を切り出し, 䋐維配向 方向にクロスヘッド速度 $0.5 \mathrm{~mm} / \mathrm{min}$ の条件で常温引張試 験を行うとともに, 光学顕微鏡による断面観察を行って, 久 陷生成状況を観察した。

\section{4 翼面形状モデル成形試験}

超塑性加工可能な長繊維強化 $\mathrm{Ti}$ 基複合材料である SCS6/SP-700 の適用先として最も有望な部品は, 航空機エンジ ンのファンブレードと考えられる. ファンブレードは空力特 性要求から複雑な複曲面形状を有しているため, 本材を用い てファンブレードに似た複曲面形状への成形試験を行い, 本 材の曲面成形適用性を明らかにすることとした。供試材とし ては, 前項と同様の溶射材抢よび Woven 材を用いた. 本成 形試験では, Fig. 4 に示すように前項と同様に SCS-6/SP700 複合材料板の上下を板厚 $1 \mathrm{~mm}$ の SP-700 板材ではさ み, この積層体を一枚の板材とみなして翼面形状にガス圧負 荷成形した。ただし, 本試験では SCS-6/SP-700 複合材料 板に必要以上に高い応力が負荷されないように，SCS-6/ SP-700 複合材料板を直接成形治具で固定せず，上下の SP700 板材で間接的に保持するよう工夫した（以下，パック成 形法と呼ぶ). 成形後の供試体については, 光学顕微鏡によ る断面観察を行って，陥生成状況の観察を行った。

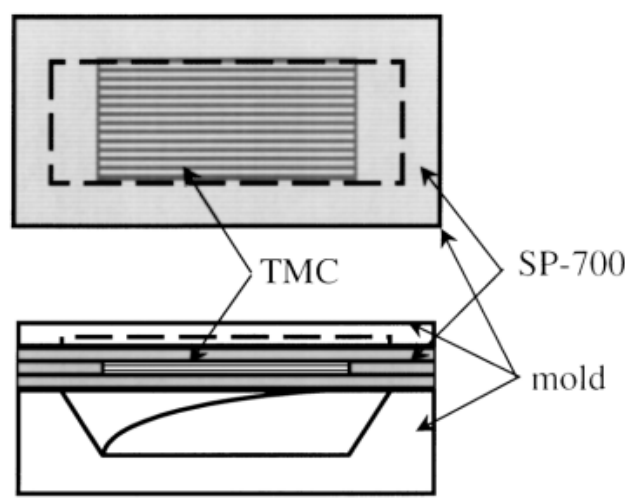

Fig. 4 Schematic of apparatus used for the fabrication of blade-shaped model using packed TMC blanks.
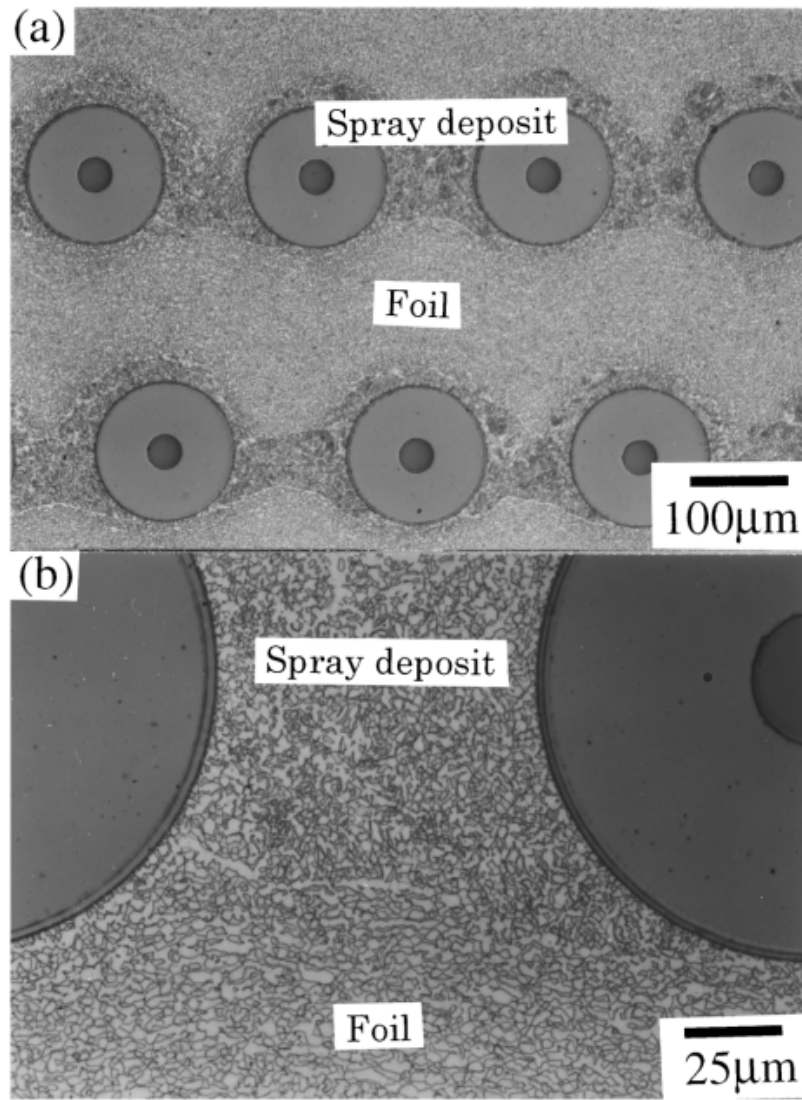

Fig. 5 Microstructure of SCS-6/SP-700 composites made of new sprayed preforms.

\section{3. 結果}

\section{1 溶射材のミクロ組織観察}

本研究では溶射皮膜部のミクロ組織を均一化するために, $\mathrm{SP}-700$ 粉末を細かく分粒して 23〜 53 $\mu \mathrm{m}$ の粒径の SP-700 粉末を用いた. 改善した溶射プリフォームを用いて製作した 溶射材のミクロ組織を Fig. 5 に示す. Fig. 5 (a)に示すよう に, 低倍率の写真では溶射皮膜部が箔部に比べてやや濃い色 にエッチングされる為に，両者は明確に区別できる。しか し, 溶射皮膜部と䈋部の境界を高倍率で観察すると, Fig. 5 (b) に示すように䈃部と溶射皮膜部の境界が明確でなく， 
䈃部と同等以上に溶射皮膜部が均一微細な組織となってい る。これは溶射粉末の粒径を細かくし，粉末粒径の違いを小 さくすることで, 溶射中の粉末溶融状態が均一化した為と考 えられる。

\section{2 常温引張試験および塑性変形特性試験}

溶射材と Woven 材の常温引張強度試験結果を Fig. 6 に示 す。溶射材の引張強度は Woven 材と比較して若干低くなっ ている.しかし，これは溶射材の $V_{\mathrm{f}}$ が $22 \%$ であるのに対し てWoven 材の $V_{\mathrm{f}}$ は $27 \%$ と高いことに起因すると考えられ る.この $V_{\mathrm{f}}$ の違いによる強度差を検討するために，次式の 複合則15)を用いる.

$$
\sigma_{\mathrm{c}}=\sigma_{\mathrm{f}} V_{\mathrm{f}}+\sigma_{\mathrm{m}}\left(1-V_{\mathrm{f}}\right)
$$

ここで $\sigma_{\mathrm{c}}$ は複合材料の最大応力, $\sigma_{\mathrm{f}}$ は強化繊維の最大応力, $\sigma_{\mathrm{m}}$ は強化繊維のひずみに相当するマトリックス単体の応力 である. 式（1）において $\sigma_{\mathrm{f}}=3500 \mathrm{MPa}, \sigma_{\mathrm{m}}=920 \mathrm{MPa}$ とし て溶射材とWoven 材の最大応力を計算すると，それぞれ $1490 \mathrm{MPa}, 1620 \mathrm{MPa}$ となり，試験結果と良く一致してお り，両者の強度レベルはほぼ同等と考えられる。

また Fig. 1（b)に示す試験片を用いて 1048 K にて行った 塑性変形特性試験結果を Fig. 7 に示す。溶射材の $m$ 值は 0.58 と従来の溶射材と同じであったが，Woven 材の $m$ 值は 0.51 と若干低くなった。複合化温度を $25 \mathrm{~K}$ 高めたことで従 来に比べ結晶粒が若干大きくなり，Woven 材の $m$ 值が低く なったと考えられる。一方，溶射材では箔部の結晶粒は Woven 材と同様に粗大化しているが， $m$ 值の低下が認めら れなかった. Woven 材に比べ溶射材の $V_{\mathrm{f}}$ が低いために顕著 な影響が認められなかった可能性がある。また溶射材の変形 応力は, Woven 材と比較して若干低く, 破断までに得られ

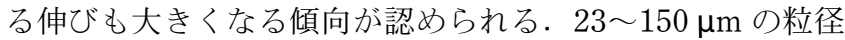
の粉末を用いて溶射プリフォームを製作し， $1023 \mathrm{~K}$ におい て複合化した溶射材の場合，同じ複合化温度のWoven 材に 比べてその変形応力が約 2 割程度高かった ${ }^{9)}$. 一方，本試験 では溶射皮膜部の組織が均一微細化したために，溶射皮膜部 の流動性が向上して変形応力が低下し，同じ複合化温度の Woven 材に比べて変形応力が低くなったものと考えられ

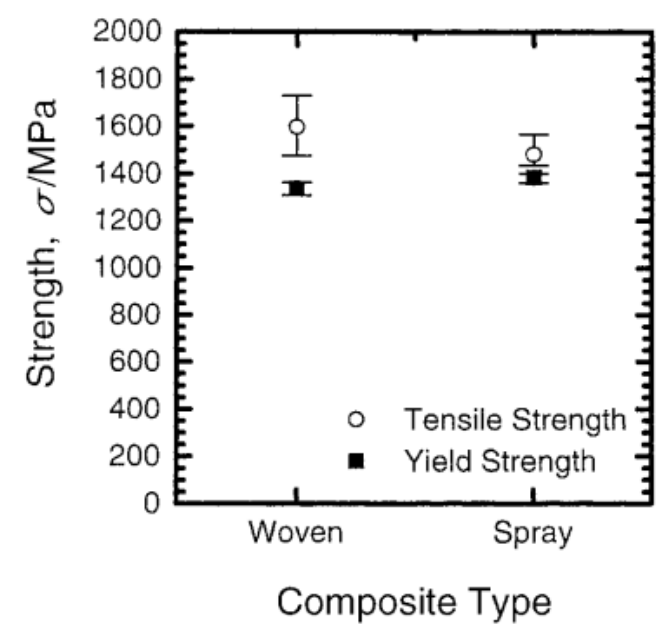

Fig. 6 Tensile strength of SCS-6/SP-700 composites.
る. 溶射皮膜部の流動特性が䈃部と同等となったと思われる 為, Woven 材より溶射材の変形応力レベルが低いのは， $V_{\mathrm{f}}$ が低いことに起因すると考えられる.

\section{3 ストリンガー形状モデル成形試験}

ガス圧負荷により成形したストリンガー形状モデルの外観 をFig. 8 に示す。モデルの底面部での板厚減少量から求め た板厚方向のひず久量 $\left(\varepsilon_{\mathrm{t}}\right)$ は, 浅いモデルで $4.9 \sim 8.4 \%$, 深 い方で $7.8 \sim 12.3 \%$ であった. $\varepsilon_{\mathrm{t}}$ の算出は次式に従って計算 した.

$$
\varepsilon_{\mathrm{t}}=-\ln \left(t / t_{0}\right)
$$

ここで， $t$ は成形後モデルの板厚， $t_{0}$ は初期板厚を示す。モ

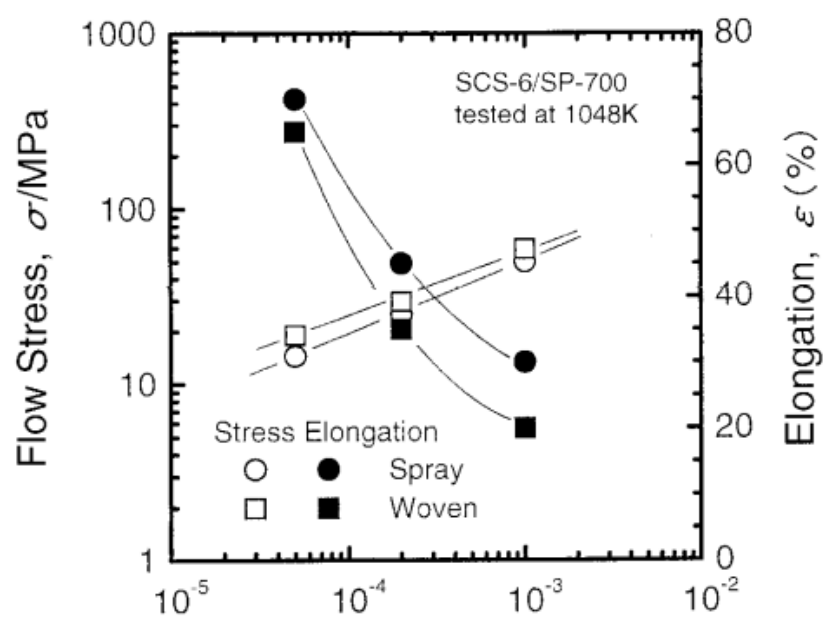

Strain Rate, $\dot{\varepsilon} / \mathrm{s}^{-1}$

Fig. 7 Deformation properties of SCS-6/SP-700 composites.

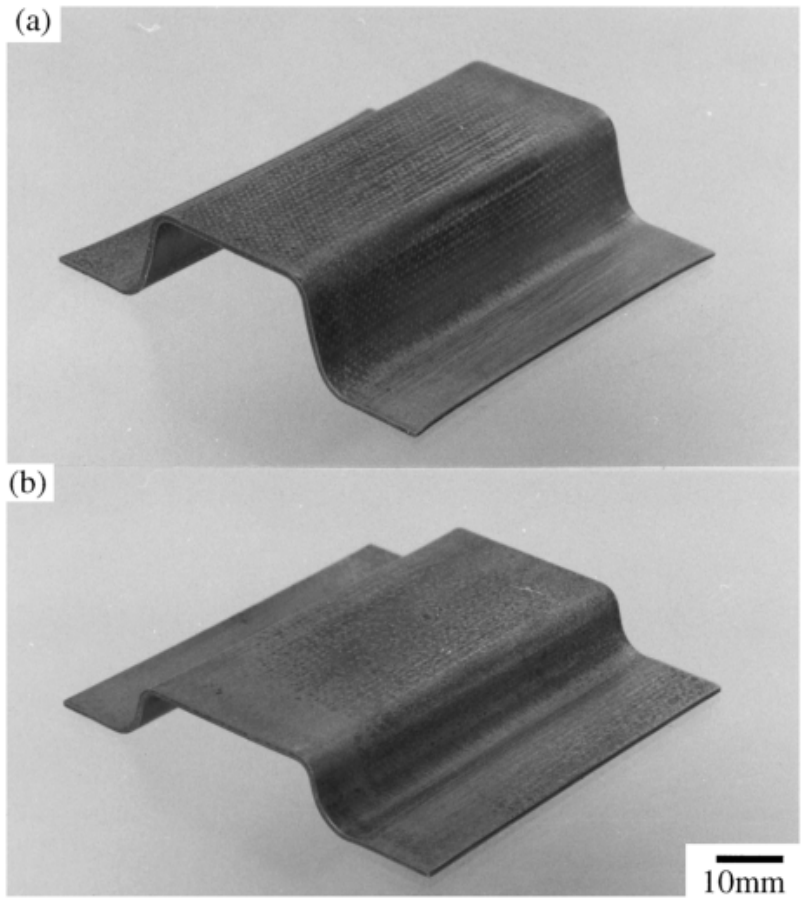

Fig. 8 Appearance of (a) deep and (b) shallow stringershaped models. 

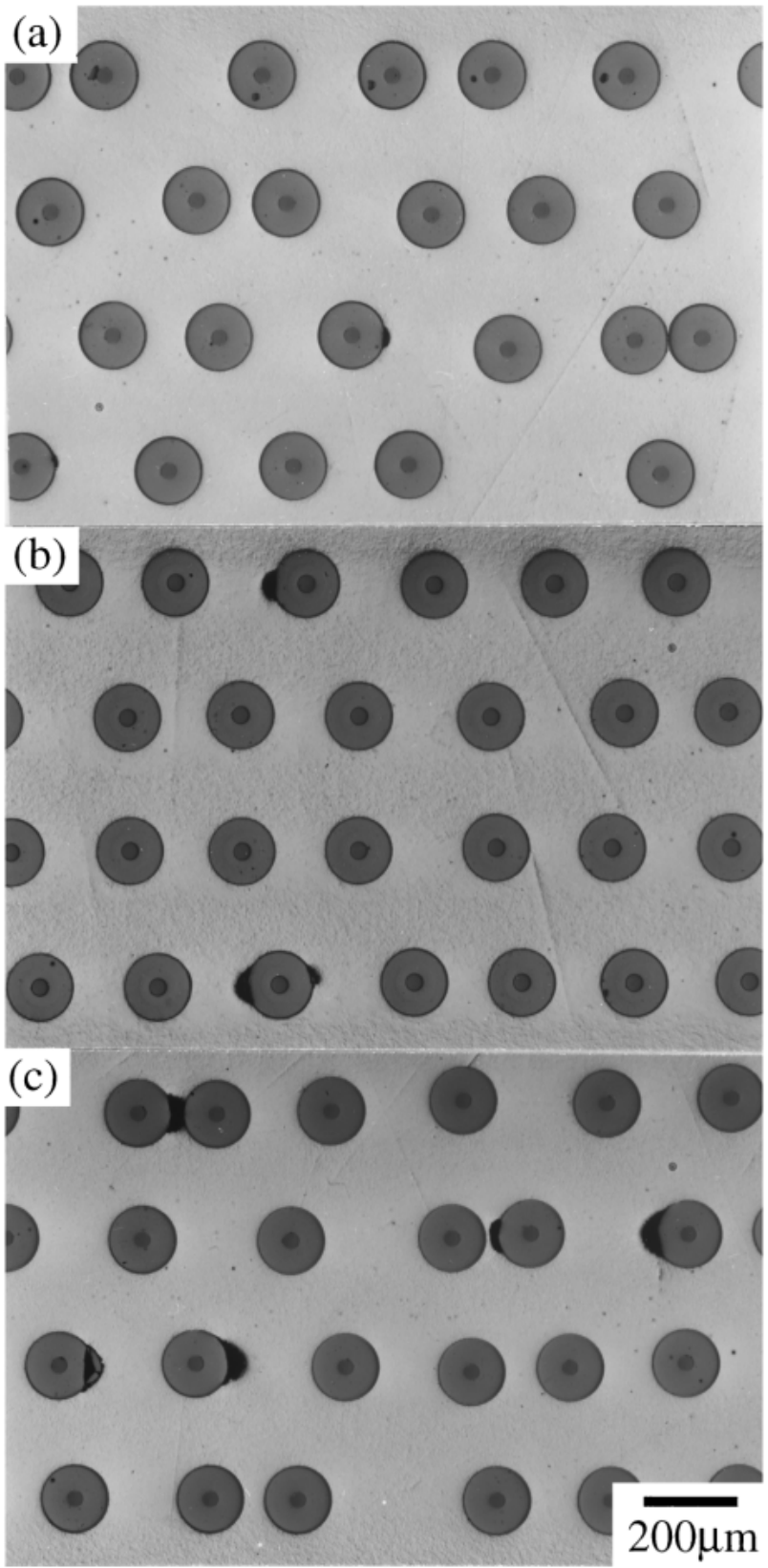

Fig. 9 Microstructure of the deep stringer-shaped models deformed under (a) $2 \times 10^{-5} \mathrm{~s}^{-1}$, (b) $5 \times 10^{-5} \mathrm{~s}^{-1}$ and (c) $5 \times$ $10^{-4} \mathrm{~s}^{-1}$ at $1048 \mathrm{~K}$

デルの底面部は強化繊維に拘束されて, 繊維方向の変形は殆 ぞ起こらない為, 平面ひずみ状態に近い状態となっており, $\varepsilon_{\mathrm{t}}$ は繊維垂直方向のひずみ量にほぼ等しいと考えられる.

また変形に伴う久陥の生成状況を観察するために，モデル の底面部から供試体を切り出し, 繊維直交方向断面での光学 顕微鏡観察を行った. Fig. 9 に深い方のモデル (Fig. 8 (a)に 示したモデル)の観察結果を示す．いずれのひずみ速度にお いても繊維/マトリックス界面での剥離欠陥が認められた. 各モデル間での欠陥生成状況を比較する為, 次式で定義する 欠陷発生率 $\left(R_{\mathrm{D}}\right)$ を各モデル毎に計算した結果と観察を行っ た場所での $\varepsilon_{\mathrm{t}}$ を併せて Fig. 10 に示す.

$$
R_{\mathrm{D}}=N / N_{\mathrm{A}} \times 100
$$

ここで, $N$ は欠陥の発生した繊維本数， $N_{\mathrm{A}}$ は全繊維本数を 表す．Fig. 10 では成形条件に強く依存する Type-1 欠陷と

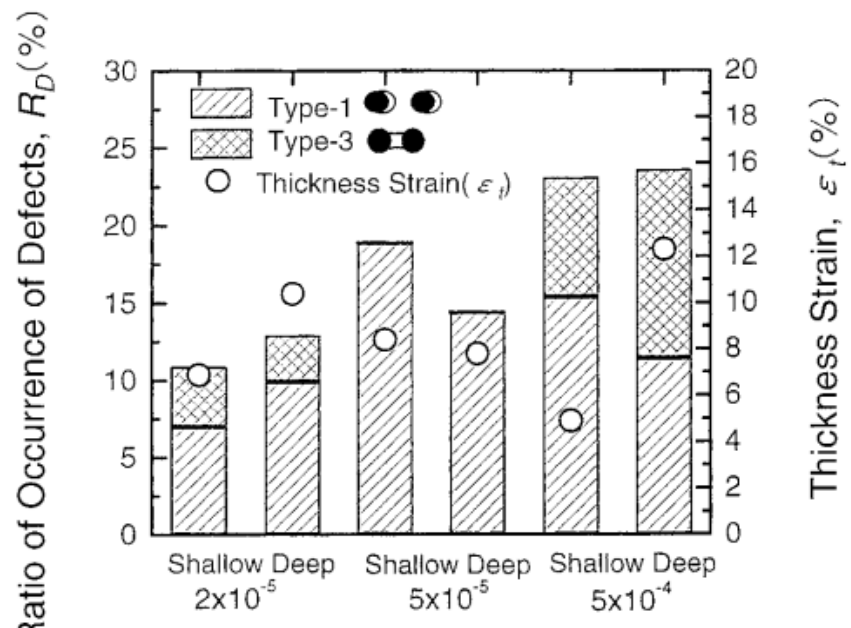

Various Types of Stringer-Shaped Model

Fig. 10 Ratio of occurrence of defects $\left(R_{\mathrm{D}}\right)$ in various stringer-shaped models.

成形条件にあまり依存しない欠陥である Type-3 欠陥を区別 して示した， 欠陥発生率はひず久速度が速くなるにつれて上 昇する傾向が認められる．これはひずみ速度の上昇に伴って 変形応力が上昇し, 㵶維/マトリックス界面での剥離が生じ 易くなった為と考えられる。一方，Fig. 9 に示した断面組織 において繊維の分布に注目してみると，ひずみ速度が $5 \times$ $10^{-5} \mathrm{~s}^{-1}$ のものは繊維がほぼ均一に分散しているが，他の 2 つの供試体では一部に繊維同土が接触している部分が認めら れる．繊維の分布状態が供試体毎に異なるのは, 溶射プリフ オームと SP-700 箔を積層する際に, 溶射プリフォームが繊 維方向に割れを生じた為であり，健全なプリフォームを用い た場合には䋊維分布が大きく乱れることはないはずである. 複合材料の $V_{\mathrm{f}}$ を高める為に溶射プリフォームの溶射皮膜厚 さをできるだけ薄く製作しようとしたことが，溶射プリフ オームを割れ易くしてしまったものと考えられる．繊維分布 が乱れたことで溶射プリフォームを利用すれば発生し難い欠 陥である Type-3 欠陥が発生してしまったと思われる。

Fig. 11 に溶射材抢よび Woven 材のストリンガー形状モ デル底面部から切り出した試験片を用いて常温引張試験を行 った結果を成形前の素材と比較して示す. Fig. 11(a)に示す ように溶射材においては, 成形前と成形後の強度に大きな差 は認められなかった。 また成形速度並びにモデルの深さの違 いに起因するひずみ量に対しても明確な依存性が認められな かった. Fig. 12 に溶射材の常温引張強度の $R_{\mathrm{D}}$ 依存性を示 す. $R_{\mathrm{D}}$ が変化しても常温強度にあまり変化はなく, 明確な 依存性も認められない。成形後の溶射材に認められた Type-1 および Type-3 欠陥は繊維に沿って細長く伸びた形 状をしており ${ }^{8)}$, 欠陥の伸びている方向と引張方向が一致す る為, 常温引張強度に対する影響が小さかったものと考えら れる。

一方, Fig. 11 (b)に示した Woven 材の常温引張強度は, 溶射材とやや異なり，成形前後で若干の強度低下が認められ る.これは Woven 材に特有の欠陥である Type-2 欠陥が繊 維方向に伸びない比較的小さな欠陥である為に ${ }^{8)}$, 複合材の 


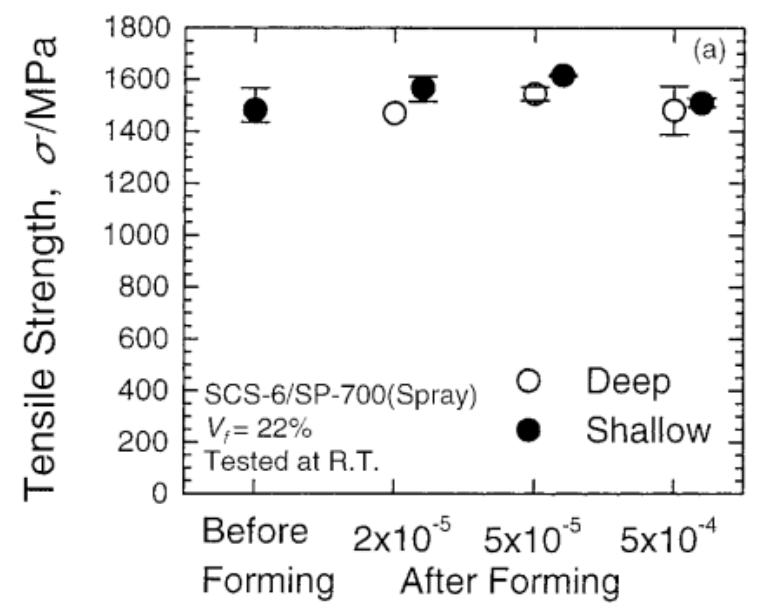

Deformation Conditions

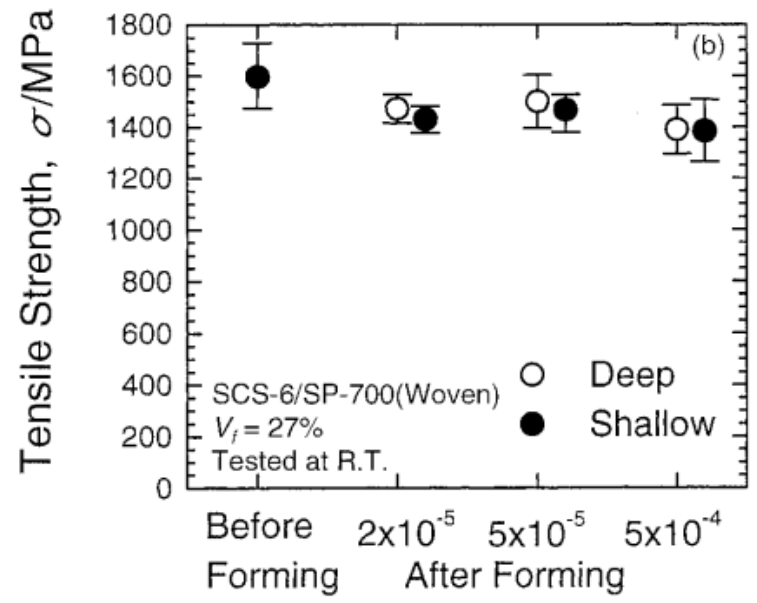

Deformation Conditions

Fig. 11 Tensile strength of SCS-6/SP-700 composites after deformation.

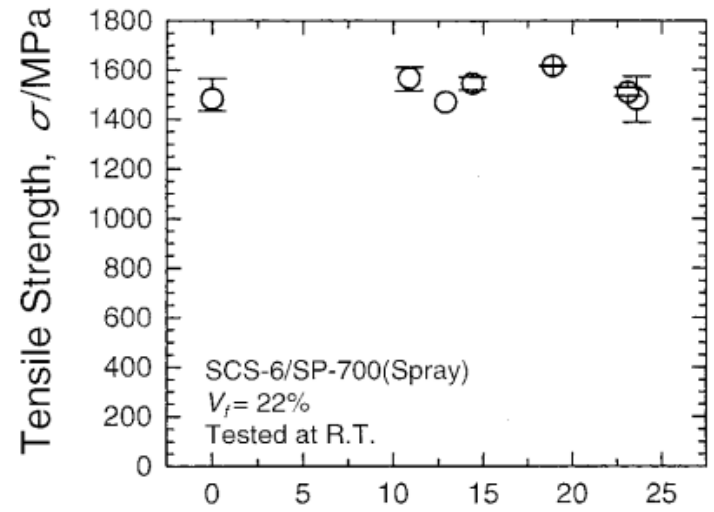

Ratio of Occurrence of Defect, $R_{D}(\%)$

Fig. 12 Relationship between tensile strength and $R_{\mathrm{D}}$.

早期破断を引き起こす破壊起点となった可能性がある.

\section{4 翼面形状モデル成形試験}

SCS-6/SP-700 複合材料の曲面成形適用性を明らかにす (a)

Tip

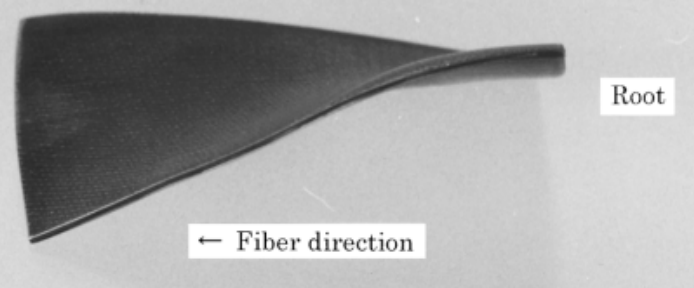

(b)

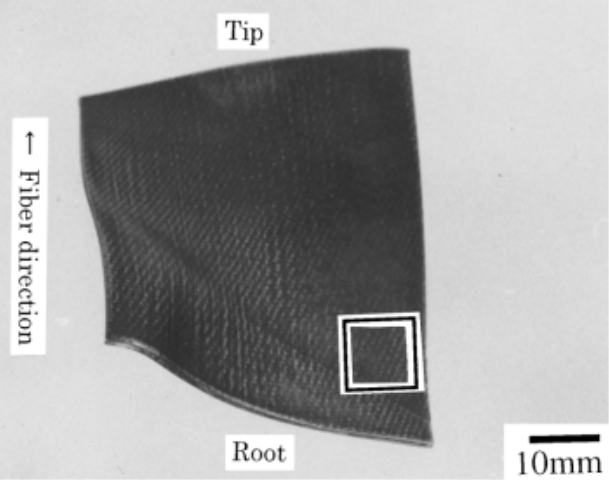

Fig. 13 Appearance of blade-shaped model.
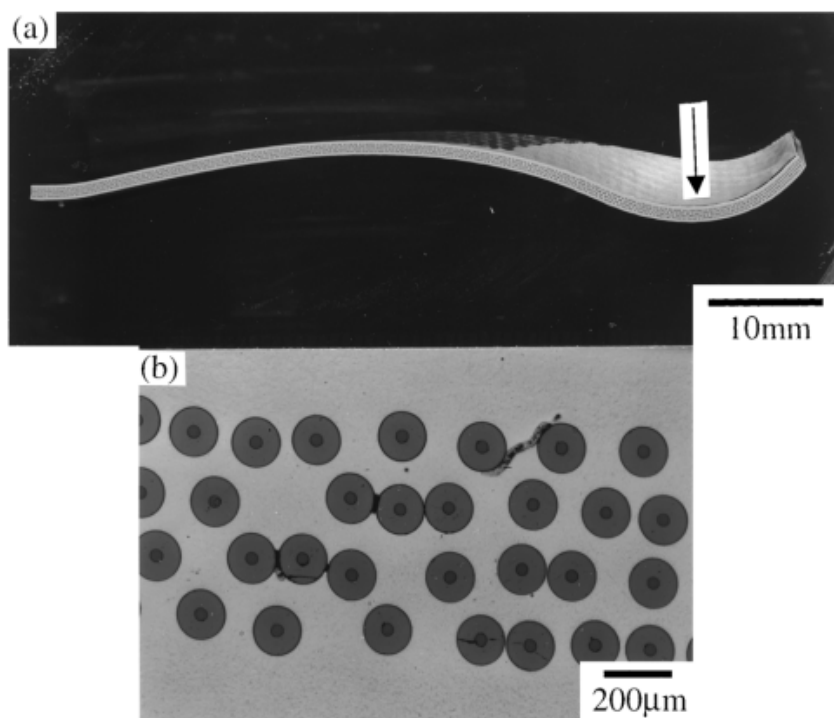

Fig. 14 Microstructure of blade-shaped model made of woven composite.

る為に，翼面形状モデルの成形試験を行った．Fig. 13 に Woven 材を用いて成形した翼面形状モデルの外観を示す. 翼のねじれ角は約 40 度あり, 翼根部では翼先端部に比べて より複雑な形状をしているものの, 成形金型と成形後素材と の密着は良好であり狙い通りの形状に成形することができ た. 翼面形状モデルの板厚から求めた $\varepsilon_{\mathrm{t}}$ は $7 \sim 14 \%$ であ り, 最も $\varepsilon_{\mathrm{t}}$ の大きい場所は Fig. 13(b)に打いて四角で囲ん だ翼根部近傍であった。 Woven 材を 